\title{
The Larval Stages of Erato voluta (Montagu).
}

\author{
By \\ Marie V. Lebour, D.Sc., \\ Naturalist at the Plymouth Laboratory. \\ With Plates 1-2.
}

Noтнгng is known of the life-history of Erato voluta (Montagu)=Erato lavis (Donovan) and in the following note the larvæ are described for the first time. Erato being very closely related to Trivia, it was to be expected that the larvæ would be somewhat similar, but, although there is here, as in Trivia, an Echinospira larva, the details of its life-history are quite different and the accessory shell when fully developed differs much from that of Trivia.

The eggs of Erato voluta have not yet been distinguished certainly although some gelatinous egg capsules laid in between the lobes of Botrylloides, but not embedded in it like Trivia, taken with Erato from outside waters, may belong to this mollusc.

Erato voluta, although not common, occurs fairly frequently singly or two or three at a time on gravel grounds from about 15 to 30 fathoms; occasionally at greater depths. It is not known on what it was feeding when taken with the dredge, but presumably its natural food, like Trivia, is compound ascidians, for it will eat largely of Diplosoma scraped from the tanks and has been kept alive for months in plunger-jars with this ascidian and also Botryllus and Botrylloides for food. It has however never deposited its eggs in captivity.

An Echinospira larva, rather like Trivia when young but differing from it in certain particulars and very different when older, is found fairly commonly in the plankton, usually singly or two or three at a time in spring and summer. It was the late larva of this form which was thought to be a Velutina and figured as "probably Velutina" in a paper on Trivia europea (Lebour, 1931, Plate IV, Fig. 2). The true Velutina larva I have now discovered and the present larva is proved to belong to Erato as it has been kept in a plunger-jar until it metamorphosed.

The youngest stage seen measures $0.64 \mathrm{~mm}$. across the accessory (Echinospira) shell, the true shell inside measuring $0.32 \mathrm{~mm}$. across (Plate 1, Fig. 1). At a first glance it looks like a very young Trivia, but seen more exactly it shows several differences. The accessory shell is 
PLATE 1.

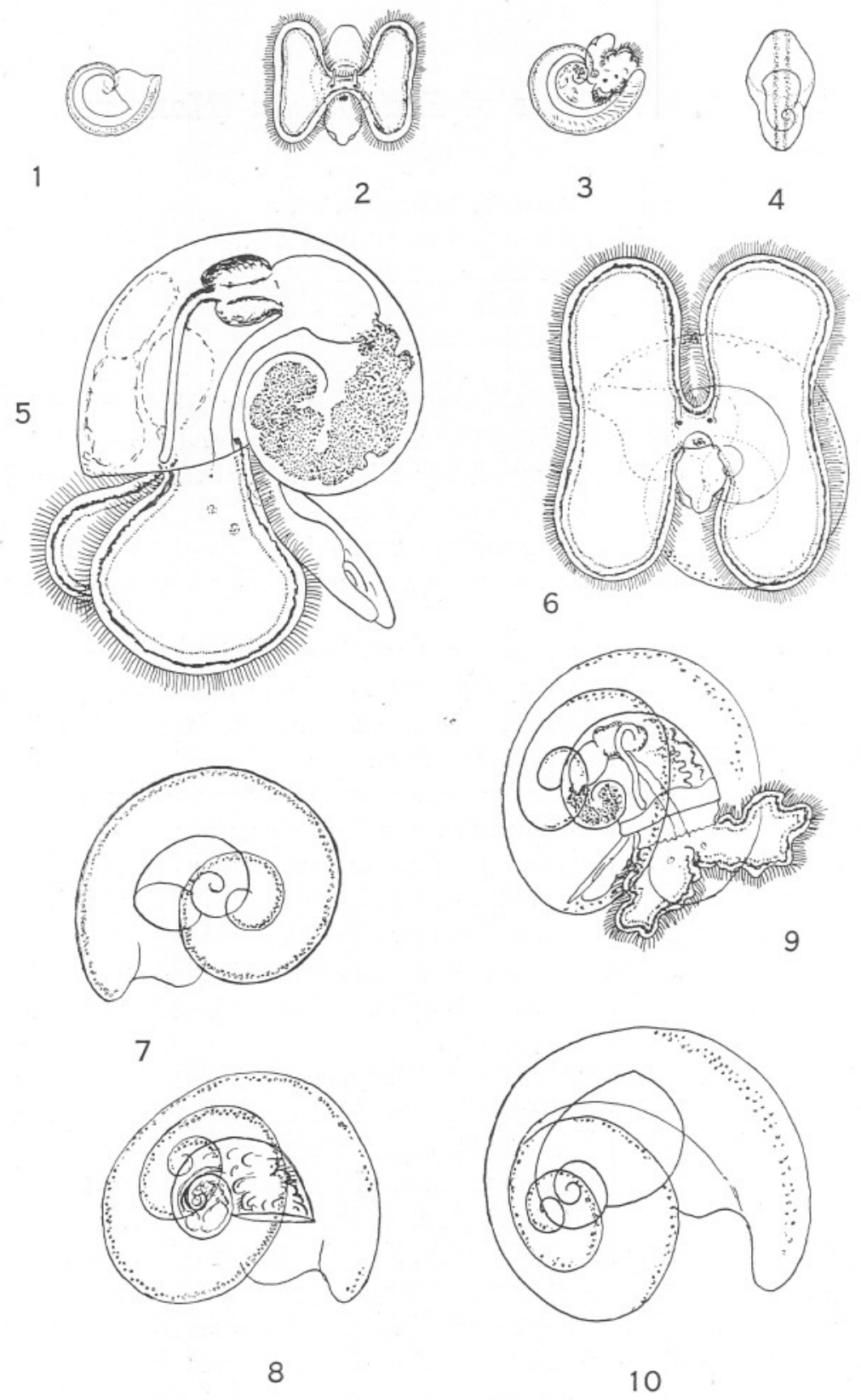


keeled at the periphery and on each side of the keel is a border of small clear dots looking like beads, two to four in a row (Plate 1, Fig. 4). The accessory shell is helicoid and, unlike Trivia, the coils do not coincide with the true shell at any time, although in these very young stages this is difficult to see. There are lines of growth on the body whorl, the inner whorls being very clear and transparent. The true shell consisting at this stage of about one and a half whorls is also very clear and transparent and lies somewhat excentrically to the accessory shell, the aperture being round. At first the animal is almost colourless or very pale yellow, but when the accessory shell is $0.80 \mathrm{~mm}$. across, the true shell being $0.40 \mathrm{~mm}$. across, there is a little dark pigment on the stomach and the beginning of the intestine which persists in the later stages. The eyes, short tentacles, and otocysts are well developed and there is a broad foot, tending to be three-lobed, somewhat pointed at the end and bearing an operculum. The velum which has a narrow brown border consisting of two larger lobes, very slightly indented at the side as the animal grows, has the usual bordering of cilia leading to the mouth (Plate 1, Fig. 2). These early stages are found from April to November both in the inside and outside plankton, usually outside, and they are commonest from May to August, rare in early spring and autumn. The later stages have a very conspicuous helicoid accessory shell, still with marginal bead-like dots, but these gradually become fainter and even obliterated in some specimens. Sometimes in the older forms none are apparent. The true shell lies quite excentrically in the accessory shell with the same structure as in the early stages, the lobes of the velum, now very large, slightly indented at the sides. Sometimes, but not usually, there are a few dark spots on the velum, irregularly placed, as well as the brown border. When the accessory shell measures about $1.9 \mathrm{~mm}$. across it has three and a half to four whorls, the last projecting at the aperture in a rounded process (Plate 1, Figs. 7-9).

\section{EXPLANATION OF PLATE 1.}

(Scale B is six times the scale of A.) Erato voluta.

PLATE 1 (Fig. 5 Scale B, the rest Scale A).

FIG. 1.-Very young larva from plankton, $0 \cdot 64 \mathrm{~mm}$. across accessory shell.

Fig. 2.-Slightly older larva from plankton, $0 \cdot 80 \mathrm{~mm}$. across.

FIG. 3.-The same, side view with velum retracted.

Frg. 4.-The same, showing keel.

FIG. 5.-True shell of same (accessory shell omitted) showing alimentary canal.

FIG. 6.-Larva from plankton, $1.90 \mathrm{~mm}$. across accessory shell.

FIG. 7.-Slightly older larval shell, showing accessory shell and true shell without animal.

Figs. 8-9.-Older larvæ from plankton.

Fig. 10.-Larval shell plankton, $2 \mathrm{~mm}$. across, showing elongation of true shell. 
PLATE 2.

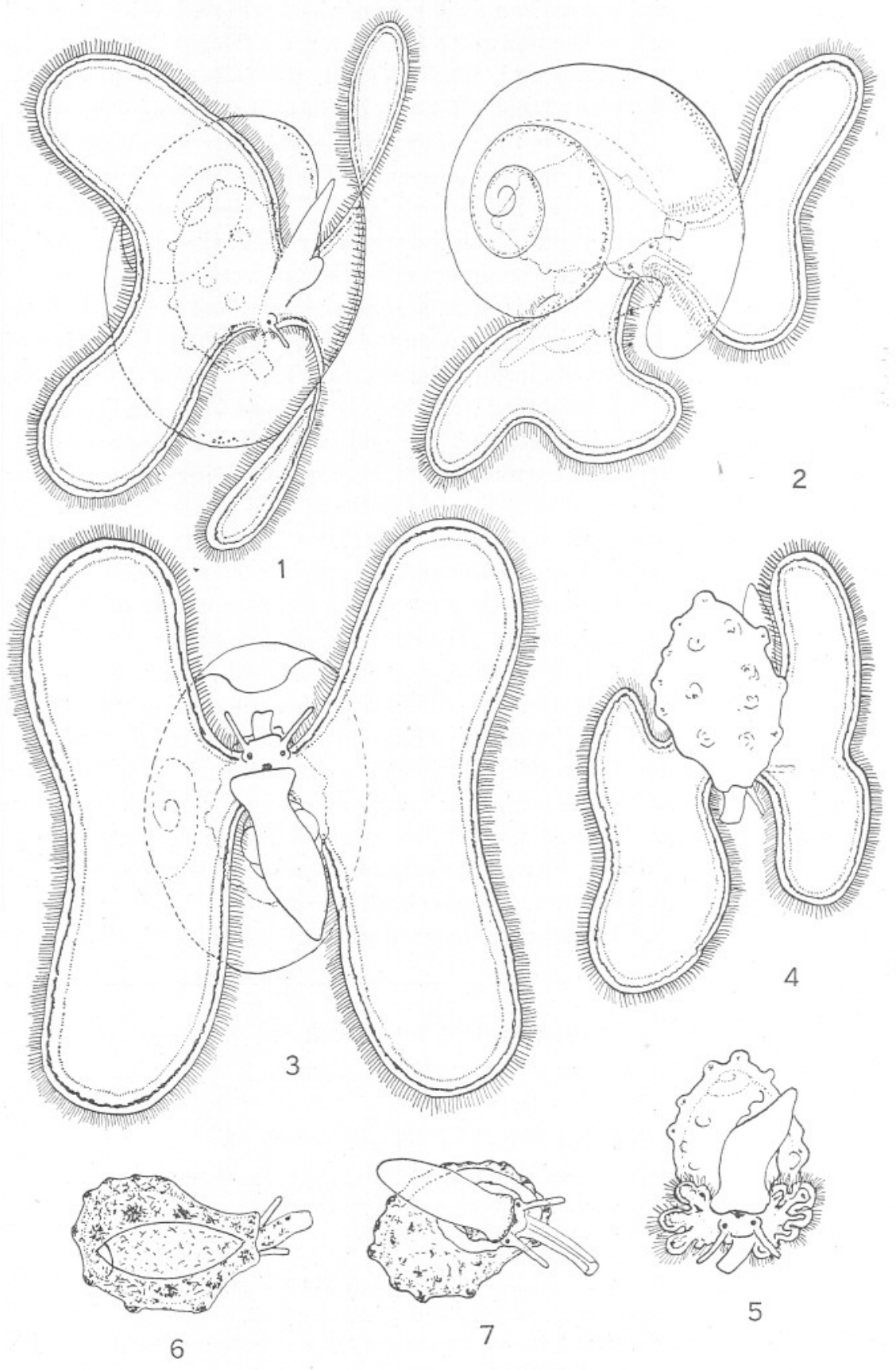


The true shell with about two and a half whorls has a very large velum, the lobes reaching well beyond the accessory lobes, the foot three-lobed, the operculum conspicuous. It is now very nearly ready to metamorphose, and the mantle forms a thick border round the aperture of the true shell which soon begins to elongate, a partial metamorphosis taking place, the accessory shell being at its largest, about $2 \mathrm{~mm}$. across and retained for some time longer. The mantle entirely surrounds the shell and is provided with conspicuous papillæ with brown and yellow pigment. No part of the true shell is left uncovered. The body whorl of the shell has elongated considerably and is not unlike a young Trivia. The siphon projects from the front end from under a fold in the mantle, the foot is still three-lobed, and is still provided with an operculum. The velum is still large, measuring about $2 \mathrm{~mm}$. across (Plate 1, Fig. 10 ; Plate 2, Figs. 1-3).

This partially metamorphosed larva swims for some time longer whilst retaining the accessory shell (Plate 2, Figs. 1-3). A late larva from the outside plankton, placed in a plunger-jar with Nitzschia for food on July 8th, 1932, metamorphosed in this way on July 17th still retaining the velum, operculum and accessory shell. The last it retained until August 2nd, when it was swimming about without it; the velum was still large but the operculum gone. A peculiar feature in the metamorphosis is that the accessory shell is shed entire and was picked up floating in the plunger-jar quite perfect. Thus Erato differs in this essential feature from Trivia in which the mantle encloses the accessory shell which is presumably eventually absorbed, and from Lamellaria which simply shrivels up, being so fragile and thin that it can no longer keep its shape. The larva after shedding the accessory shell measured $1.25 \mathrm{~mm}$. in length, the shell being $1.04 \mathrm{~mm}$. long (Plate 2, Fig. 4). The foot is elongated and has lost the lateral lobes which supported the operculum. The tentacles are fairly long, the siphon well developed, the eyes conspicuous, and the velum only slightly smaller, but still forming an effective swimming organ. Here again is a distinct difference from Trivia and Lamellaria in which the velum disappears at metamorphosis. The mantle has dark brown and yellow pigment especially on the numerous papillæ which

\section{EXPLANATION OF PLATE 2.}

(Scale B is six times the scale of A.)

Erato voluta.

\section{PLATE 2 (Scale A).}

Figs. 1-3.-Larvæ from plankton kept for some weeks in a plunger-jar showing metamorphosed animal still in the accessory shell, $2 \mathrm{~mm}$. across.

FIG. 4.-Larva having lost the accessory shell.

Fig. 5.-The same with velum dwindling.

Figs. 6-7.-The same completely metamorphosed, $1.25 \mathrm{~mm}$. long. 
stand out from it in a conspicuous manner. A few days later the velum is dwindling and although still able to swim the larva spends much time at the bottom of the jar (Plate 2, Fig. 5). The velum remained for three weeks more. On August 24th it had disappeared, but the animal had not grown. Even early in September it was still the same size, but had altered considerably (Plate 2, Figs. 6-7), the siphon being very long, the colour much darker having a network of brown pigment on the papillæ and mantle both outside and on the lines inside the shell, and there is a very large muscular proboscis capable of protrusion for a long way. There is now a separation of the sides of the mantle leaving the shell exposed dorsally as in the adult. The animal is now like the adult except for the thickening of the shell and the colouring which is at present mainly brown with very little yellow and no red has as yet appeared, the adult animal being spotted with red on the foot and siphon. A difference from Trivia is seen in the siphon which comes from below the dorsal mantle so that there is a fold between them, whereas in Trivia it is continuous with the dorsal mantle.

Small pieces of Diplosoma had been placed in the plunger-jar and although the young Erato was not seen to eat it must almost certainly have eaten this as it was well and healthy.

Although the adult Erato voluta is very like Trivia in the animal, the form of the shell distinguishes it at once, the spire being exposed and the shell smooth. The elucidation of its larval history fully justifies their separation into distinct genera. The life-history is peculiar and the larvæ behave in a totally different way from those of Trivia-indeed, from those of any known molluscan larvæ.

On August 11th two individuals were pairing in a plunger-jar. This was provided with a piece of a hard bryozoon on which grew some small masses of Botrylloides from deep water, but no eggs were laid.

\section{LITERATURE.}

Lebour, M. V. 1931. The Eggs and Larvæ of Trivia europea. Journ. Mar. Biol. Assoc., N.S., Vol. XVIII, No. 3, pp. 819-830. 